\title{
Evaluation of Susceptibility of Different Pear Hybrid Populations to Fire Blight (Erwinia amylovora)
}

\author{
Yasemin EVRENOSOĞLU' ${ }^{1}$, Adalet MISIRLI², Hikmet SAYGILI ${ }^{3}$ \\ Emre BİLEN² ${ }^{2}$ Özlem BOZTEPE², Nihal ACARSOY² \\ ${ }^{1}$ Eskişehir Osmangazi University, Faculty of Agriculture, Department of Horticulture, Eskişehir, Turkey; yevrenosoglu@ogu.edu.tr \\ ${ }^{2}$ Ege University, Faculty of Agriculture, Department of Horticulture, Bornova, Izmir, Turkey \\ ${ }^{3}$ Ege University, Faculty of Agriculture, Department of Plant Protection, Bornova, Izmir, Turkey
}

\begin{abstract}
Fire blight disease caused by pathogenic bacterium Erwinia amylovora, is the serious disease of pear, and there is not a certain chemical management against this disease except antibiotic-type compounds such as streptomycin. It is very important to improve new fire blight resistant cultivars in case of integrated disease management. With this purpose, different crosses have been made between Pyrus communis varieties that have good fruit characteristics and resistant cultigens. Besides, self and open pollination treatments have been carried out in maternal plants. The disease resistance level of the hybrids obtained from these combinations was determined by artificial inoculations by Erwinia amylovora in greenhouse conditions. A total of 3284 hybrids were inoculated, and 2631 of them survived and were distributed to different susceptibility classes. $19.88 \%$ of the inoculated hybrids was killed by Erwinia amylovora. Total distribution of the hybrids to susceptibility classes was as $6.18 \%$ in class "A- slightly susceptible", 3.11\% in class "B- less susceptible", $8.89 \%$ in class "C-mid-susceptible", 20.28\% in class "D- susceptible", and 61.54\% in class "E- very susceptible". Majority of class "A- slightly susceptible" hybrids were obtained from 'Magness' x 'Ankara' combination. 'Kieffer' x 'Santa Maria, 'Kieffer' open pollination, 'Magness' x 'Akça', 'Magness' x 'Kieffer,' 'Magness' x 'Santa Maria, 'Mustafa Bey' x 'Moonglow' treatments displayed good results with respect to "A- slightly susceptible" character. It is very important to evaluate these hybrid pear populations through different fruit and tree characteristics in the future.
\end{abstract}

Keywords: artificial inoculation, breeding, Erwinia amylovora, pear, resistance, susceptibility

\section{Introduction}

Fire blight disease, caused by Erwinia amylovora, is one of the most destructive diseases of pear (Pyrus communis) in the world and affects some other species in the Rosaceae family (van der Zwet and Beer, 1995). It is stated that growers and scientists would agree that fire blight is like no other plant disease. For growers, fire blight is a capricious bacterial disease which can decimate apple and pear orchards in a single season, thus limiting areas where most susceptible apple and pear varieties can be grown. Today, fire blight is spread almost all over the world where pear trees are grown. So far, mountains and oceans have not been able to keep fire blight at bay (Vanneste, 2000).

It was indicated that, once fire blight became established in the Egypt-Cyprus-Israel triangle, it was only a matter of time before the disease appeared in neighbouring countries. In 1985, fire blight was reported from the coastal areas of Turkey and the following year from the island of Crete in Greece (Momol et al., 1992; Vanneste, 2000). In Turkey, the disease spread rapidly across the country from west to east and was particularly severe on quince (Cydonia oblonga) and medlar (Mespilus spp.) (Momol et al., 1992).
Pear species were ranked in descending order, based on their degree of fire blight resistance, Pyrus ussuriensis, Pyrus calleryana, Pyrus betulaefolia, Pyrus pyrifolia and Pyrus communis (Shay et al., 1962; Vanneste, 2000).

Although there is no certain solution for the disease, mechanical and chemical management can be performed. Biological methods have started to be used recently against the disease (Aysan et al., 1999; Sobiczewski et al., 1997). Today only heavy metals and antibiotic-type compounds are registered for control of fire blight; the best antibiotic, streptomycin, is not registered in every country where fire blight occurs and, as pointed out earlier, development of streptomycin-resistant strains compromises its effectiveness (Vanneste, 2000). Improving resistant cultivars is one of the main objectives of the integrated management of bacterial diseases. Using resistant cultivars, rootstocks and interstocks come into primary prominence in controlling fire blight disease (Bergamaschi et al., 2006; Layne and Quamme, 1975).

Up to date, lots of breeding programs have been performed by crossing cultivars with different resistance levels to attain resistant varieties. Several simple and complex hybridization programmes have been used on fire blight resistance breeding of pear (Bergamaschi et al., 2006; Du- 
rel et al., 2004; Fischer and Mildenberger, 2000; Hevesi et al., 2004; Hunter and Layne, 2004; Layne and Quamme, 1975; Ryugo, 1982; Sobiczewski et al., 1997; Thibault and Lezec, 1990). On this matter, it was stated that, it is possible to be successful by choosing resistant parents in disease resistance breeding (Layne and Quamme, 1975).

With respect to the above mentioned explanations, this project has started with the aim of obtaining resistant and high quality cultivars by crossing susceptible but qualified commercial cultivars grown in our country and worldwide with resistant commercial cultivars and local cultigens. In this scope, controlled hybridizations have been performed between susceptible and resistant pear genotypes and susceptibility levels of hybrids were detected by artificial inoculations that were conducted using Erwinia amylovora.

\section{Materials and methods}

The current study was conducted between 2007 and 2010. Hybridization studies were performed at Ege University, Ödemiş Vocational Training School and Atatürk Central Horticultural Research Institute in 2007 and 2008.

The cultivars listed in Tab. 1 were used in hybridization treatments. With this purpose, different crosses have been planned between susceptible ('Akça', 'Mustafa Bey', 'Santa Maria,' 'Williams') or resistant ('Güz', 'Magness', 'Kieffer') P. communis varieties (O), and resistant or moderately resistant cultigens (J) (Aysan et al., 1999; Bell et al., 2005; Çıtır and Mirik, 1999; Honty et al., 2006; McGraw, 2006; Momol et al., 1992; Öden, 1999; Sobiczewski et al., 1997; Ünal et al., 1998; van Der Zwet and Beer, 1991).

Hybridizations were performed between cultivars that bloom in the same period as susceptible $\mathrm{x}$ susceptible, susceptible $\mathrm{x}$ resistant, resistant $\mathrm{x}$ susceptible and resistant $\mathrm{x}$ resistant combinations (Rosati et al., 2002).

Pollen, which was used for hybridization studies was provided from the balloon stage buds of the parents, chosen as pollinators (Layne and Quamme, 1975). In terms of

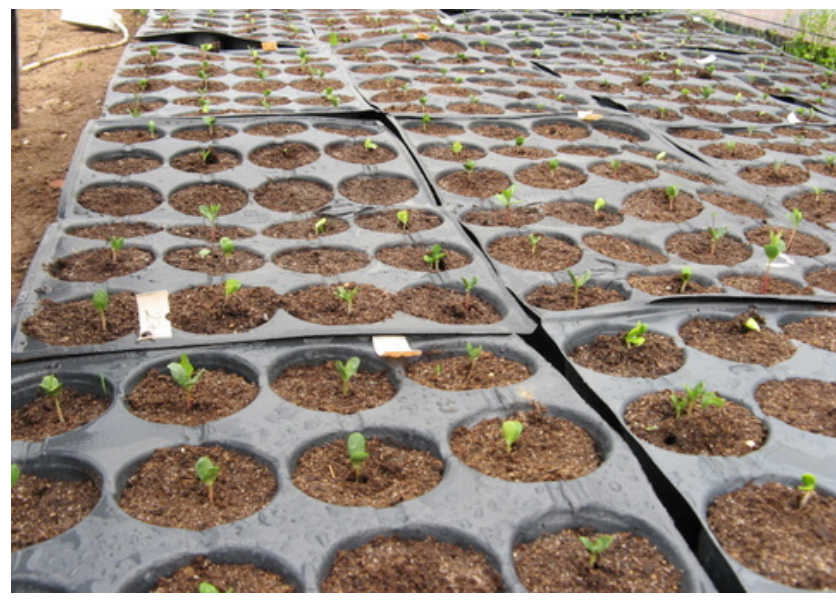

a
Tab. 1. Cultivars and cultigens used in hybridization treatments

\begin{tabular}{|c|c|c|}
\hline Maternal Parents & & Pollinators \\
\hline 'Akça' & \multirow{8}{*}{$\frac{\stackrel{\Xi}{\Xi}}{\Xi}$} & 'Ankara' \\
\hline ‘Güz’ & & 'Cleveland Select' \\
\hline 'Kieffer' & & 'Conference' \\
\hline 'Magness' & & 'Dancer' \\
\hline 'Mustafa Bey' & & 'Kaiser Alexandre' \\
\hline 'Santa Maria' & & 'Kieffer' \\
\hline \multirow[t]{7}{*}{ 'Williams' } & & 'Limon' \\
\hline & & 'Moonglow' \\
\hline & \multirow{5}{*}{ 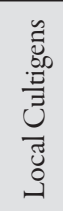 } & 'Bursa' \\
\hline & & ‘Güz' \\
\hline & & 'Taş' \\
\hline & & 'Ekşi' \\
\hline & & 'Pamuk Akçası' \\
\hline
\end{tabular}

hybridization studies, 3 flowers per cluster were emasculated by removing petals and anthers. One day after emasculation, pistils were pollinated (Layne and Quamme, 1975). As for self-pollination, pink bud stage buds were isolated. For open pollination, buds on the shoots were counted and labelled. In every combination, almost 500 buds were emasculated. These treatments were carried out for three consecutive years (Evrenosoglu et al., 2010).

Ripened fruits were harvested; then, seeds were stratified at $2-4^{\circ} \mathrm{C}$ for 90 days. After stratification, seeds were transplanted to vials containing peat, and after germination (Fig. 1a), they were transmitted to a media consisting of sand, manure and soil (Layne and Quamme, 1975). Hybrids were grown for one or two years in polyethylene bags (Fig. 1b).

Susceptibility levels of the obtained hybrids were detected by artificial inoculations with $E$. amylovora. With this target, 15 strains, previously isolated and identified as E. amylovora by Aysan et al. (2004), inoculated three shoots of pear for each strain. After disease symptoms on pear shoots, bacteria were re-isolated and identified by tra-

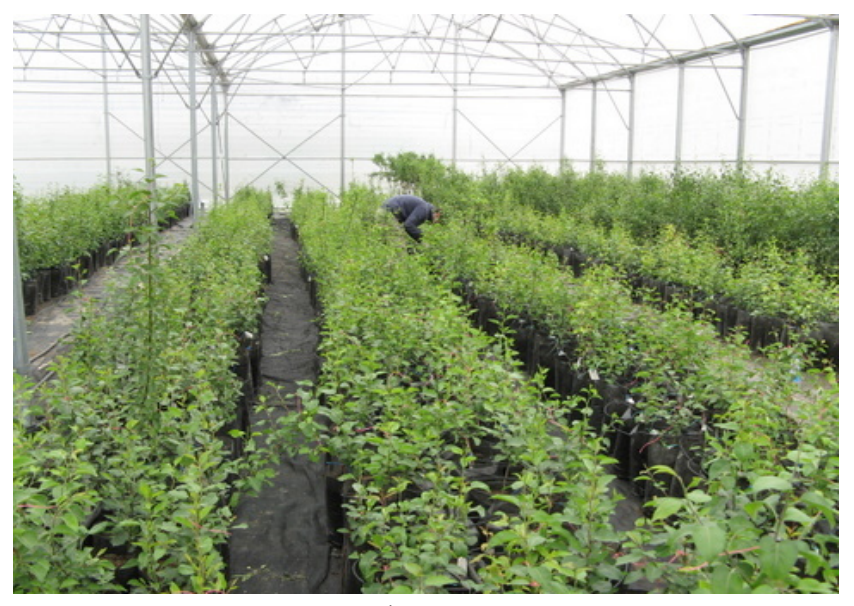

b

Fig. 1. (a) Germination and (b) growing of hybrids 


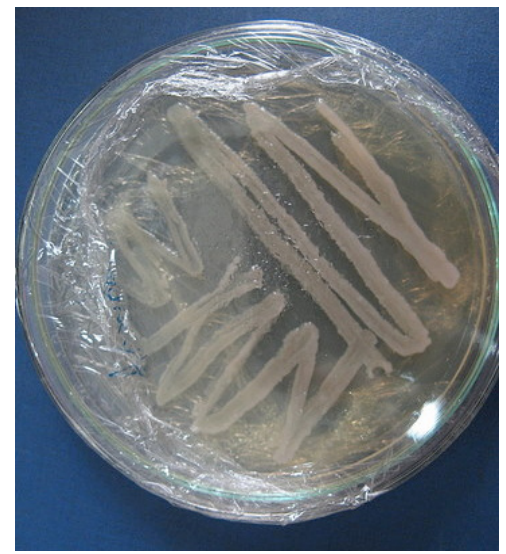

a

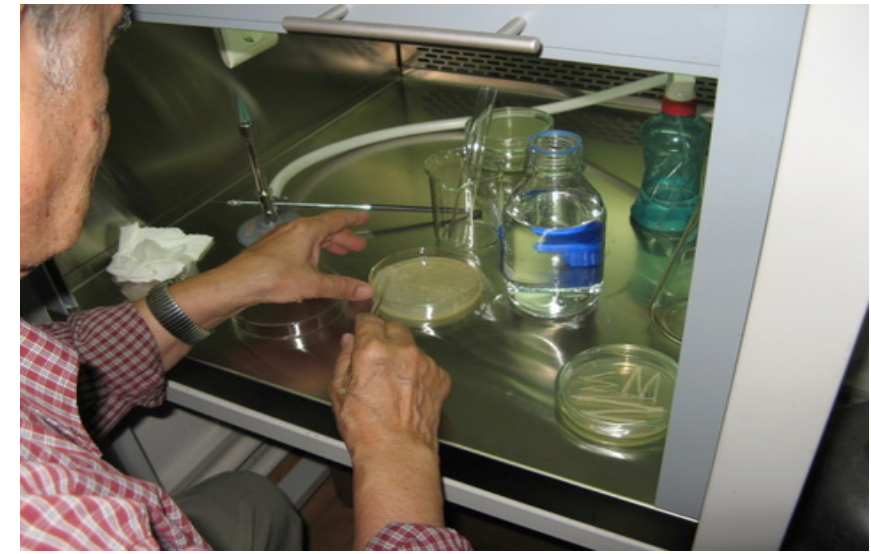

$\mathrm{b}$

Fig. 2. (a) Growth of Erwinia amylovora on the media and (b) preparation for inoculum

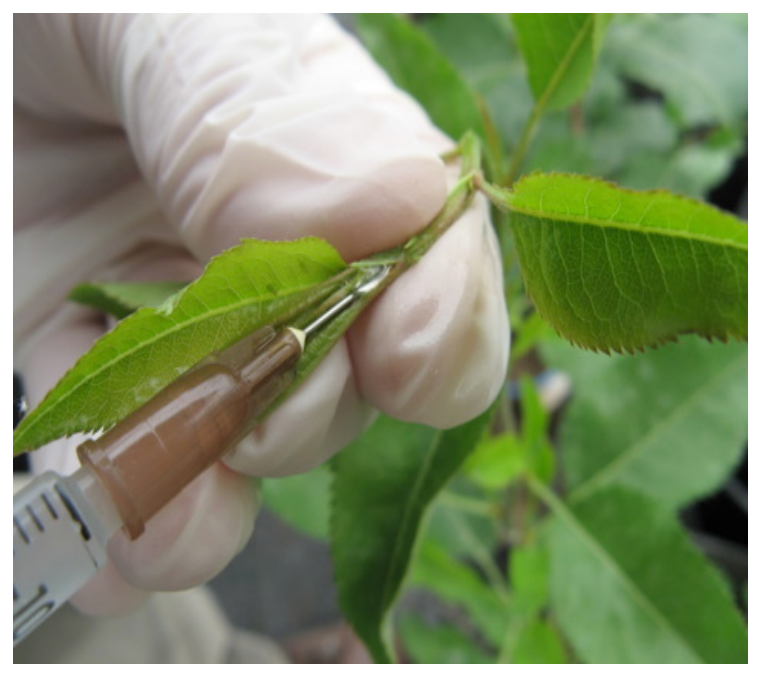

a

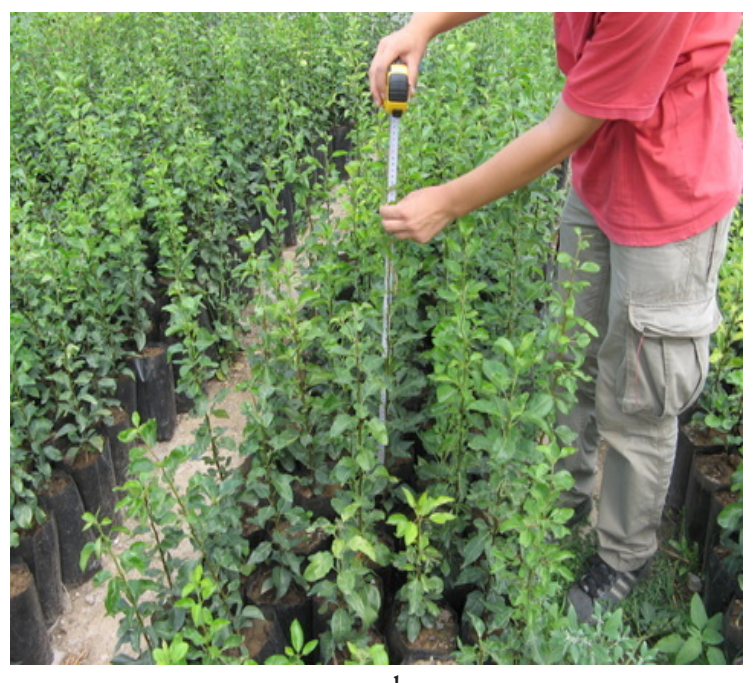

$\mathrm{b}$

Fig. 3. (a) Inoculation and (b) measuring of shoots

ditional methods (colony morphology on King's medium $\mathrm{B}, \mathrm{HR}$ test on tobacco leaves and bacterial exudate on immature pear fruits) and serology by ELISA. The highly virulent strains (AP-1 and AP-2) were selected for further inoculation studies. Using ELISA and MIS methods were provided from Çukurova University, Faculty of Agriculture, Department of Plant Protection. Each of the pathogenic bacteria strains AP-1 and AP-2 were streaked on King's medium $\mathrm{B}$ plates and incubated at $25^{\circ} \mathrm{C}$ for $48 \mathrm{~h}$. Bacterial suspensions were prepared from the strains and the density was adjusted to approximately $10^{8} \mathrm{cell} / \mathrm{ml}$ by spectrophotometer at $600 \mathrm{~nm}$ (Fig. 2a and b) (Thibault and Lezec, 1990).

Inoculations were performed by injecting an equal mix of the each inoculum suspensions using a sterile 26 numbered syringe into the apex of the shoots (Fig. 3a).

Inoculation was carried out in two periods, the first was at the second week of May 2010, and the second was at the first week of August 2010, when the shoots of hybrids reached a length of $15-20 \mathrm{~cm}$. In each hybrid, lenght of 1 or 2 shoots according to the plant's growing condition was measured and recorded (Fig. 3b). This application was done at $25-30^{\circ} \mathrm{C}$ heat and $80-90 \%$ relative humidity con- ditions (Quamme et al., 1976). These conditions are necessary for the development of fire blight disease and were met in a greenhouse.

Disease development continued for 8 weeks and at the end of this period, infected parts of inoculated shoots were measured (Fig. 4a), recorded, cut and removed (Fig. 4b). Susceptibility level of the shoots to fire blight, was found out by the formula below (Thomson et al., 1962):

$$
\text { Susceptibility of shoot }=\frac{\text { Lenght of infected part }(\mathrm{cm})}{\text { Total shoot lenght }(\mathrm{cm})} \times 100
$$

Thus, the susceptibility level for each hybrid was determined as average value of two different inoculation periods. Then, the data were classified according to Tab. 2 , and susceptibility classes and characters of hybrids were detected (Fig. 5A-E) (Thibault et al., 1987).

After determining susceptibility classes, hybrids were counted for their susceptibility level in each hybrid combination, and grouped for 2007 and 2008 treatments. Then, hybrids in combinations for two years were assembled, counted, and distribution of hybrids to susceptibility classes was calculated as percentage (Işık and Çelik, 2009). 


\section{Results and discussion}

Hybrid numbers in susceptibility classes belong to different cross combinations and treatments in 2007 can be seen in Tab. 3 .

As it was seen in Tab. 3, a total of 105 hybrids were in class "A", 38 hybrids were in class "B", 68 hybrids were in class "C", 161 hybrids were in class "D", and 300 hybrids were in class "E". 44 of inoculated 672 hybrids were killed by Erwinia amylovora. For combinations of 'Akça' maternal parent, 7 hybrids took place in class "A", and 69 were in class "E". Number of hybrids increased from class "A" to " $E$ ". There was only one hybrid in 'Akça' x 'Conference' combination and it included in class " $E$ ". Only two hybrids were obtained from 'Güz' open pollination, and 1 hybrid was in class " $D$ ", and the other was in class " $E$ ". In comparision of maternal parents, fire blight resistant 'Magness' cultivar had relatively maximum hybrids (70) for "slightly susceptible- A", and minimum hybrids (60) for “very susceptible- E”. Additionally, 'Magness' x 'Ankara' combination possessed the highest hybrid number (45) in class "A" among all combinations. Besides, total hybrid loss (6) was low in 'Magness' cultivar. In 'Mustafa Bey' cultivar, distribution of hybrids was as 15 class "A", 6 class "B", 10 class " $C$ ", 16 class "D", and 26 class "E". On the other hand, maximum hybrid number in class " $\mathrm{A}$ " was found in "Mustafa Bey' x 'Moonglow' combination, whereas, maximum hybrid number in class " $E$ " was found in 'Mustafa Bey' $x$ 'Williams' combination. On the first year of the hybridizations, few hybrids were obtained in 'Santa Maria' combi-
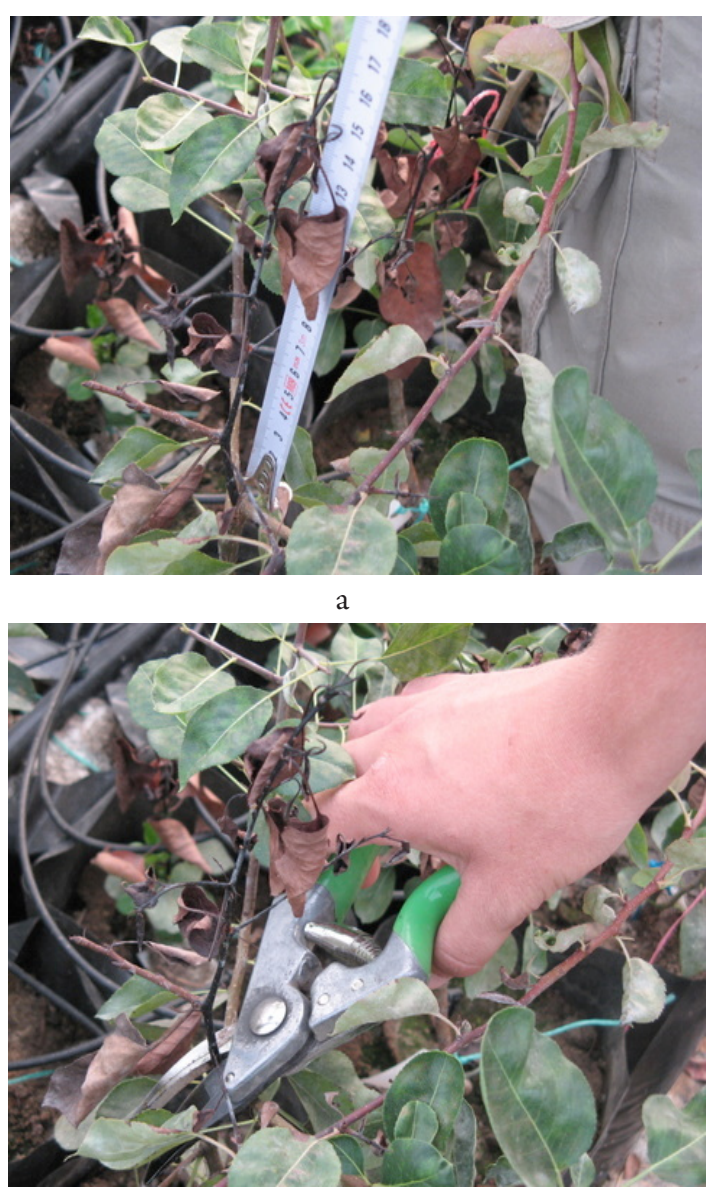

b

Fig. 4. (a) Measuring and (b) removing infected shoots
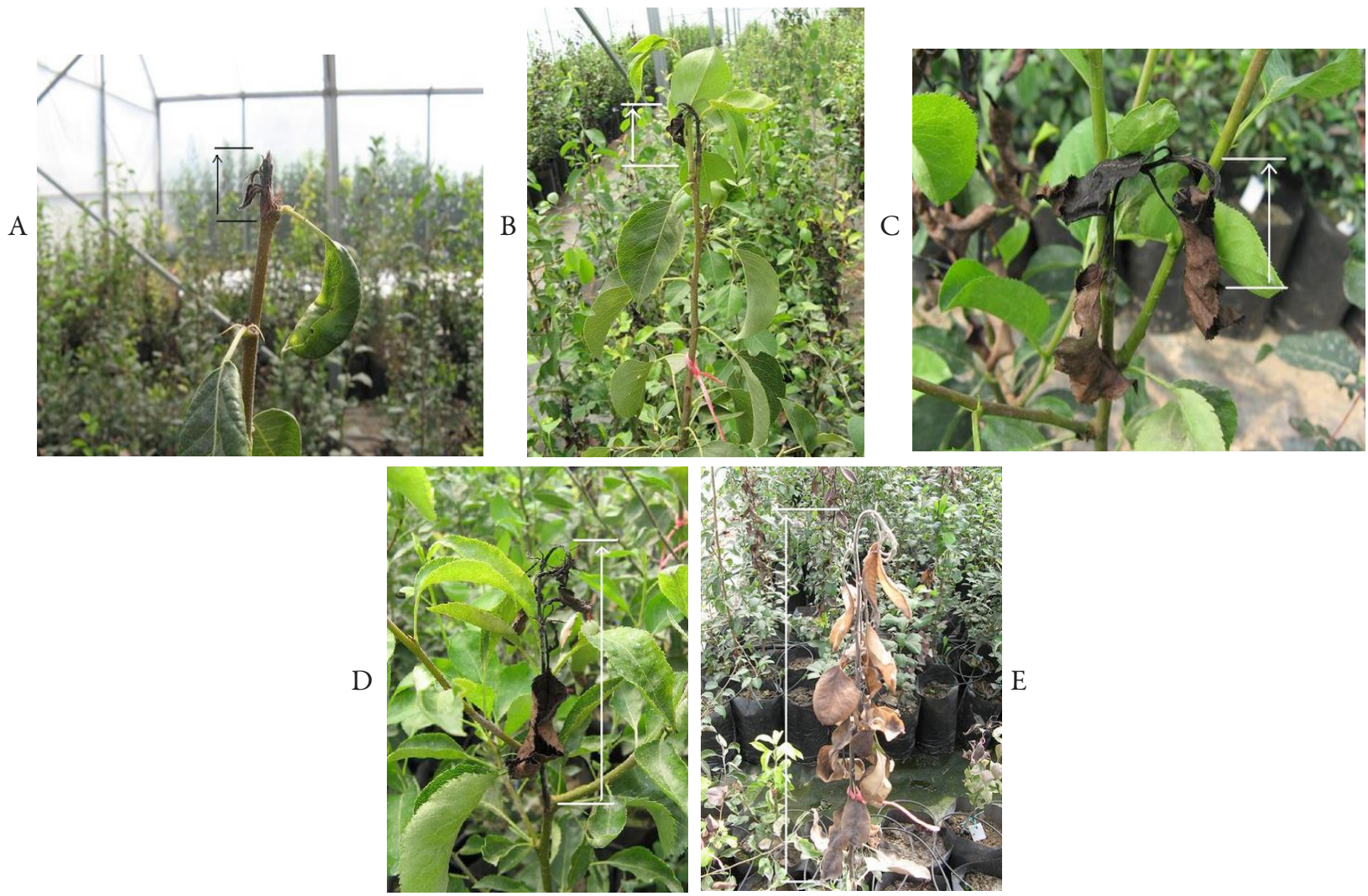

Fig. 5. Susceptibility classes (A-E) 
230

Tab. 2. Evaluation of the susceptibility by artificial inoculation (Thibault et al., 1987)

\begin{tabular}{cccccc}
\hline Susceptibility of hybrid (\%) & $0-10$ & $11-20$ & $21-40$ & $41-60$ & $61-100$ \\
\hline Susceptibility class & A & B & C & D & E \\
Susceptibility character & Slightly susceptible & Less susceptible & Mid-susceptible & Susceptible & Very susceptible \\
\hline
\end{tabular}

Tab. 3. Hybrid numbers in susceptibility classes belong to different cross combinations and treatments in 2007

\begin{tabular}{|c|c|c|c|c|c|c|c|c|}
\hline \multicolumn{9}{|c|}{ Hybrid numbers of resistance groups } \\
\hline Combination & $\mathrm{A}$ & $\mathrm{B}$ & $\mathrm{C}$ & $\mathrm{D}$ & $\mathrm{E}$ & Total of inoculated hybrids & Hybrid loss & Total of surviving hybrids \\
\hline \multicolumn{9}{|c|}{ 'Akça' combinations } \\
\hline 'Conference' & - & - & - & - & 1 & 1 & - & 1 \\
\hline Open pollination & 7 & 10 & 12 & 36 & 68 & 133 & 12 & 121 \\
\hline Total & 7 & 10 & 12 & 36 & 69 & 134 & 12 & 122 \\
\hline \multicolumn{9}{|c|}{ 'Güz' combinations } \\
\hline Open pollination & - & - & - & 1 & 1 & 2 & - & 2 \\
\hline Total & - & - & - & 1 & 1 & 2 & - & 2 \\
\hline \multicolumn{9}{|c|}{ 'Magness' combinations } \\
\hline 'Akça' & 9 & 3 & 5 & 6 & 8 & 31 & 2 & 29 \\
\hline 'Ankara' & 45 & 10 & 11 & 33 & 32 & 131 & 1 & 130 \\
\hline ‘Güz’ & 1 & 2 & 4 & 5 & 7 & 19 & 1 & 18 \\
\hline 'Kieffer' & - & - & - & 1 & - & 1 & - & 1 \\
\hline 'Limon’' & 4 & 1 & 4 & 12 & 6 & 27 & 2 & 25 \\
\hline 'Taş' & 4 & 2 & 3 & 3 & 3 & 15 & - & 15 \\
\hline Open pollination & 7 & 1 & 4 & 7 & 4 & 23 & - & 23 \\
\hline Total & 70 & 19 & 31 & 67 & 60 & 247 & 6 & 241 \\
\hline \multicolumn{9}{|c|}{ 'Mustafa Bey' combinations } \\
\hline ‘Güz’ & 2 & - & - & 2 & 4 & 8 & 1 & 7 \\
\hline 'Moonglow' & 11 & 4 & 8 & 11 & 7 & 41 & - & 41 \\
\hline 'Williams' & 2 & 2 & 2 & 3 & 15 & 24 & - & 24 \\
\hline Total & 15 & 6 & 10 & 16 & 26 & 73 & 1 & 72 \\
\hline \multicolumn{9}{|c|}{ 'Santa Maria' combinations } \\
\hline 'Akça' & - & - & 1 & - & 3 & 4 & 1 & 3 \\
\hline 'Cleveland Select' & 1 & 1 & - & 1 & 3 & 6 & 1 & 5 \\
\hline 'Kieffer' & - & - & - & - & 2 & 2 & - & 2 \\
\hline 'Limon’ & - & - & 1 & 1 & 2 & 4 & - & 4 \\
\hline 'Taş̧ & - & - & - & 1 & 1 & 2 & - & 2 \\
\hline Open pollination & 2 & - & - & - & - & 2 & - & 2 \\
\hline Total & 3 & 1 & 2 & 3 & 11 & 20 & 2 & 18 \\
\hline \multicolumn{9}{|c|}{ 'Williams' combinations } \\
\hline 'Akça' & 1 & 1 & 1 & 2 & 6 & 11 & - & 11 \\
\hline 'Ankara' & 2 & - & 4 & 13 & 37 & 56 & 6 & 50 \\
\hline 'Bursa' & - & - & - & 3 & 20 & 23 & 3 & 20 \\
\hline 'Conference' & - & - & - & 2 & 10 & 12 & 2 & 10 \\
\hline 'Dancer' & - & - & 2 & 2 & 5 & 9 & 2 & 7 \\
\hline 'Ekşi' & - & - & - & 1 & 1 & 2 & 1 & 1 \\
\hline ‘Güz’ & 1 & - & - & 3 & 10 & 14 & 3 & 11 \\
\hline 'Kaiser Alexandre' & 2 & 1 & 1 & 2 & 11 & 17 & 2 & 15 \\
\hline 'Kieffer' & - & - & 1 & - & 3 & 4 & - & 4 \\
\hline 'Limon' & 1 & - & - & - & 1 & 2 & - & 2 \\
\hline 'Moonglow' & 1 & - & 1 & 1 & 1 & 4 & - & 4 \\
\hline 'Pamuk Akçası' & - & - & - & - & 1 & 1 & - & 1 \\
\hline 'Santa Maria' & 2 & - & 2 & 4 & 6 & 14 & - & 14 \\
\hline 'Taş’ & - & - & - & 3 & 13 & 16 & 2 & 14 \\
\hline Open pollination & - & - & 1 & 2 & 8 & 11 & 2 & 9 \\
\hline Total & 10 & 2 & 13 & 38 & 133 & 196 & 23 & 173 \\
\hline Final total & 105 & 38 & 68 & 161 & 300 & 672 & 44 & 628 \\
\hline
\end{tabular}


Tab. 4. Hybrid numbers in susceptibility classes belong to different cross combinations and treatments in 2008

\begin{tabular}{|c|c|c|c|c|c|c|c|c|}
\hline \multicolumn{9}{|c|}{ Hybrid numbers of resistance groups } \\
\hline Combination & A & $\mathrm{B}$ & $\mathrm{C}$ & $\mathrm{D}$ & $\mathrm{E}$ & $\begin{array}{c}\text { Total of } \\
\text { inoculated } \\
\text { hybrids }\end{array}$ & $\begin{array}{c}\text { Hybrid } \\
\text { loss }\end{array}$ & $\begin{array}{c}\text { Total of } \\
\text { surviving } \\
\text { hybrids }\end{array}$ \\
\hline \multicolumn{9}{|c|}{ 'Akça' combinations } \\
\hline 'Conference' & 1 & - & 2 & 7 & 40 & 50 & 22 & 28 \\
\hline ‘Güz’ & - & - & - & - & 3 & 3 & 1 & 2 \\
\hline 'Kaiser Alexandre' & 1 & 1 & - & 2 & 16 & 20 & 8 & 12 \\
\hline 'Kieffer' & 4 & - & 1 & 2 & 8 & 15 & 2 & 13 \\
\hline 'Moonglow' & - & - & 1 & - & - & 1 & - & 1 \\
\hline 'Santa Maria' & - & - & 1 & 3 & 10 & 14 & - & 14 \\
\hline 'Taş' & - & - & - & - & 4 & 4 & - & 4 \\
\hline 'Williams' & - & 1 & 1 & - & 15 & 17 & 4 & 13 \\
\hline Open pollination & - & - & 2 & 9 & 25 & 36 & 9 & 27 \\
\hline Total & 6 & 2 & 8 & 23 & 121 & 160 & 46 & 114 \\
\hline \multicolumn{9}{|c|}{ 'Kieffer' combinations } \\
\hline 'Santa Maria' & 12 & 6 & 50 & 105 & 201 & 374 & 24 & 350 \\
\hline Open pollination & 16 & 10 & 44 & 46 & 114 & 230 & 14 & 216 \\
\hline Total & 28 & 16 & 94 & 151 & 315 & 604 & 38 & 566 \\
\hline \multicolumn{9}{|c|}{ 'Magness' combinations } \\
\hline 'Akça' & 13 & 6 & 9 & 21 & 35 & 84 & 7 & 77 \\
\hline 'Kieffer' & 11 & 10 & 28 & 13 & 11 & 73 & 2 & 71 \\
\hline 'Santa Maria' & 12 & 16 & 17 & 26 & 35 & 106 & 6 & 100 \\
\hline 'Taş' & 4 & 1 & - & 3 & 10 & 18 & - & 18 \\
\hline 'Williams' & 1 & - & - & - & 2 & 3 & 2 & 1 \\
\hline Open pollination & 4 & 1 & 5 & 9 & 14 & 33 & 3 & 30 \\
\hline Total & 45 & 34 & 59 & 72 & 107 & 317 & 20 & 297 \\
\hline \multicolumn{9}{|c|}{ 'Santa Maria' combinations } \\
\hline 'Akça' & - & - & - & 1 & 6 & 7 & 1 & 6 \\
\hline 'Bursa' & - & - & - & - & 1 & 1 & - & 1 \\
\hline ‘Güz’ & - & 1 & 1 & 6 & 23 & 31 & 8 & 23 \\
\hline 'Kieffer' & - & - & 1 & 5 & 18 & 24 & 7 & 17 \\
\hline ‘Taş’ & 1 & - & - & 3 & 12 & 16 & 1 & 15 \\
\hline 'Williams' & - & - & 3 & 22 & 109 & 134 & 26 & 108 \\
\hline Open pollination & 7 & 2 & 12 & 29 & 131 & 181 & 43 & 138 \\
\hline Total & 8 & 3 & 17 & 66 & 300 & 394 & 86 & 308 \\
\hline \multicolumn{9}{|c|}{ 'Williams' combinations } \\
\hline 'Akça' & 3 & 2 & 11 & 54 & 95 & 165 & 14 & 151 \\
\hline 'Ankara' & 2 & 4 & 9 & 60 & 403 & 478 & 227 & 251 \\
\hline 'Bursa' & - & - & 1 & - & 2 & 3 & 1 & 2 \\
\hline ‘Güz’ & - & - & 1 & 8 & 19 & 28 & 4 & 24 \\
\hline 'Kieffer' & 2 & 2 & 12 & 30 & 104 & 150 & 37 & 113 \\
\hline 'Taş' & 1 & - & 1 & 4 & 115 & 121 & 67 & 54 \\
\hline Open pollination & 3 & 1 & 11 & 37 & 140 & 192 & 69 & 123 \\
\hline Total & 11 & 9 & 46 & 193 & 878 & 1137 & 419 & 718 \\
\hline Final total & 98 & 64 & 224 & 505 & 1721 & 2612 & 609 & 2003 \\
\hline
\end{tabular}

nations (20), and much of these hybrids (11) were placed in class "E". When it comes to 'Williams' combinations, totaly 133 of 196 hybrids took part in class "E", and only 10 of them were in class " $\mathrm{A}$ " (Tab. 3).

In a general evaluation according to Tab. 4, "A", "B", "C" "D" and "E" classes owned 98, 64, 224, 505, and 1721 hybrids, respectivelly in 2008. 609 of inoculated 2612 hy- brids were killed by disease. Inoculated hybrid number of 'Akça' cultivar was 160, and only 6 of them were in class "A". The significant amount of the inoculated 'Akça' hybrids existed in class "E" (121), and 46 of them were lost because of this disease. In 'Kieffer' combinations, there were 604 hybrids and a total of 28 of them were placed in class "A". Most of the hybrids were in class " $D$ " (151), and "E" 
232

(315), in addition 94 hybrids were determined as "midsusceptible- C". When 'Kieffer' x 'Santa Maria' combination (12) and 'Kieffer' open pollination treatment (16) compared, there were much more "slightly susceptible- A" hybrids in open pollination application. As for 'Magness' combinations, there were relatively more class "A" hybrids (45) than the other maternal parents, and this situation is due to 'Magness' is a resistant cultivar (Honty et al., 2006; Mcgraw, 2006). The amount of "slightly susceptible- A" hybrids ranged between 1 ('Magness' $x$ 'Williams') and 13 ('Magness' $\mathrm{x}$ 'Akça') according to the cross combinations. For 'Santa Maria' parent, only 8 of the 394 hybrids were observed in class "A". One of these hybrids was obtained from 'Taş' pollinator, and the others were from open pollination. Most of the hybrids were present in "very suscep- tible- E” character (300). In 'Williams' cultivar, similar to 'Santa Maria' cultivar, class "A" had few hybrids (11). 878 hybrids of inoculated 1137 hybrids included in "very susceptible-E" character, and 419 of hybrids were killed owing to Erwinia amylovora. Most of the killed hybrids belong to the 'Williams' $x$ 'Ankara' combination (Tab. 4).

In both years, it was noticed that the amount of "slightly susceptible- A" hybrids were detected much more in combinations of resistant maternal parents like 'Magness' and 'Kieffer', when compared to combinations of susceptible maternal parents ('Akça', 'Santa Maria,' 'Williams'). Controversely, when these resistant cultivars are used as pollinators, it could not be possible to get the same promising conclusion. Besides, even if we use susceptible cultivars as pollinators for these resistant maternal parents,

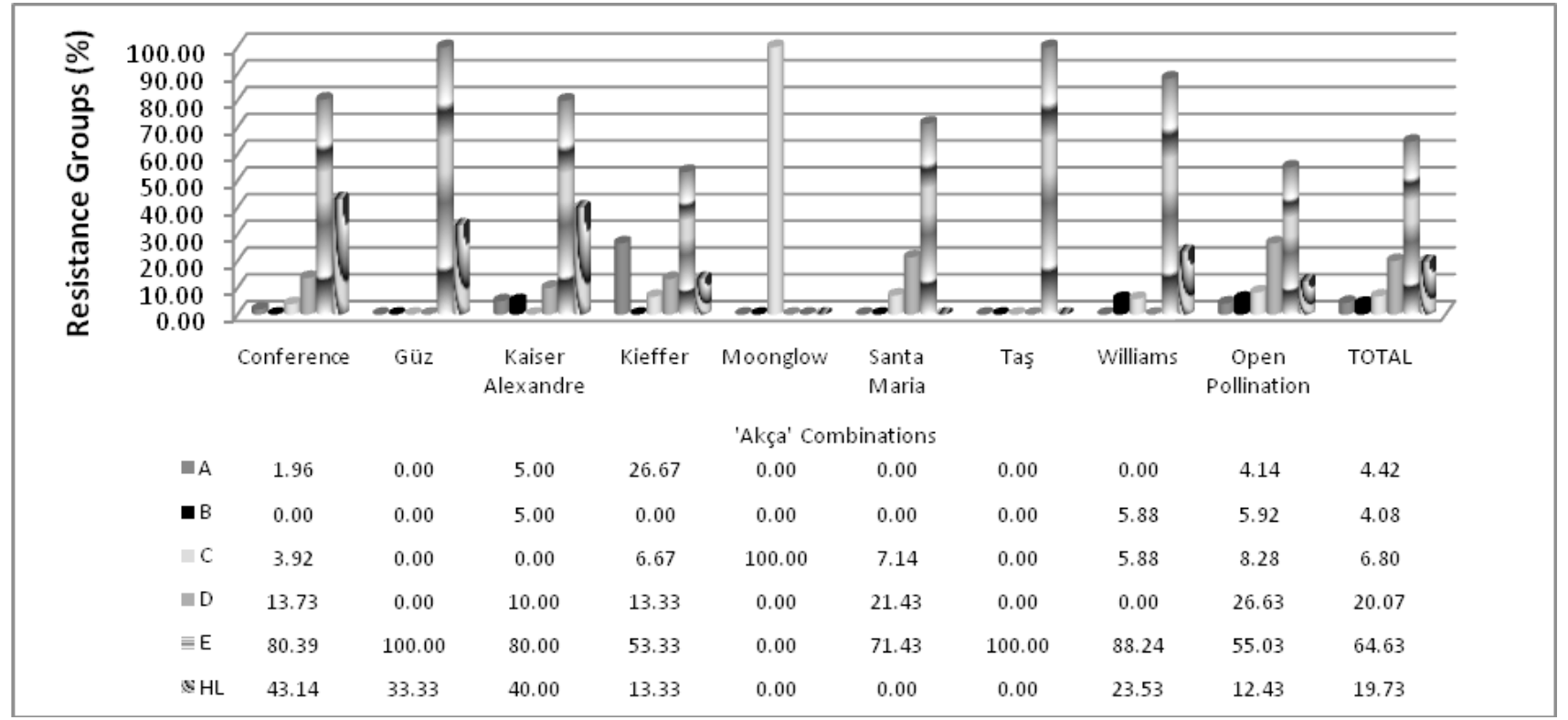

Fig. 6. Distribution of 'Akça' hybrids to susceptibility classes (\%)

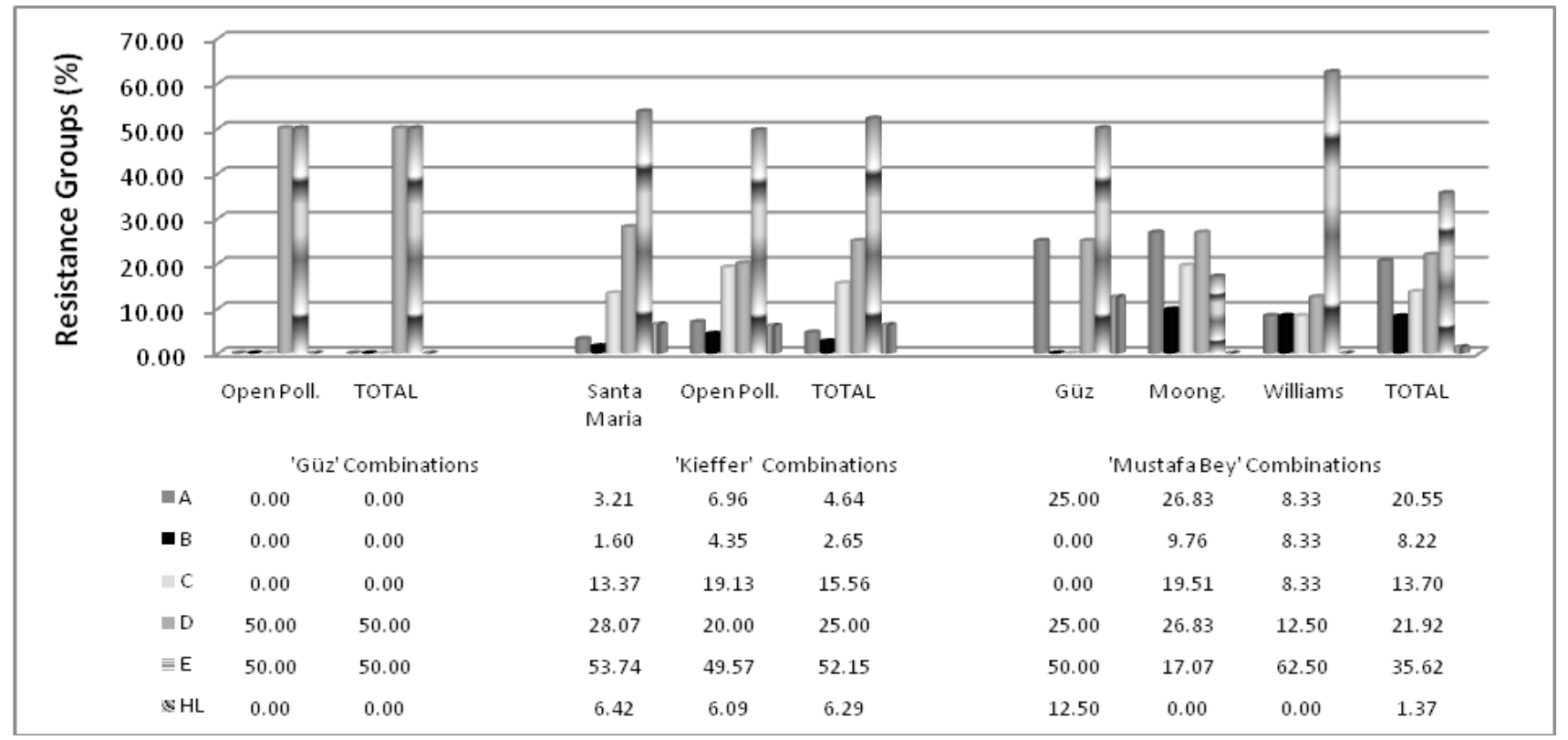

Fig. 7. Distribution of 'Güz,' 'Kieffer' and 'Mustafa Bey' hybrids to susceptibility classes (\%) 


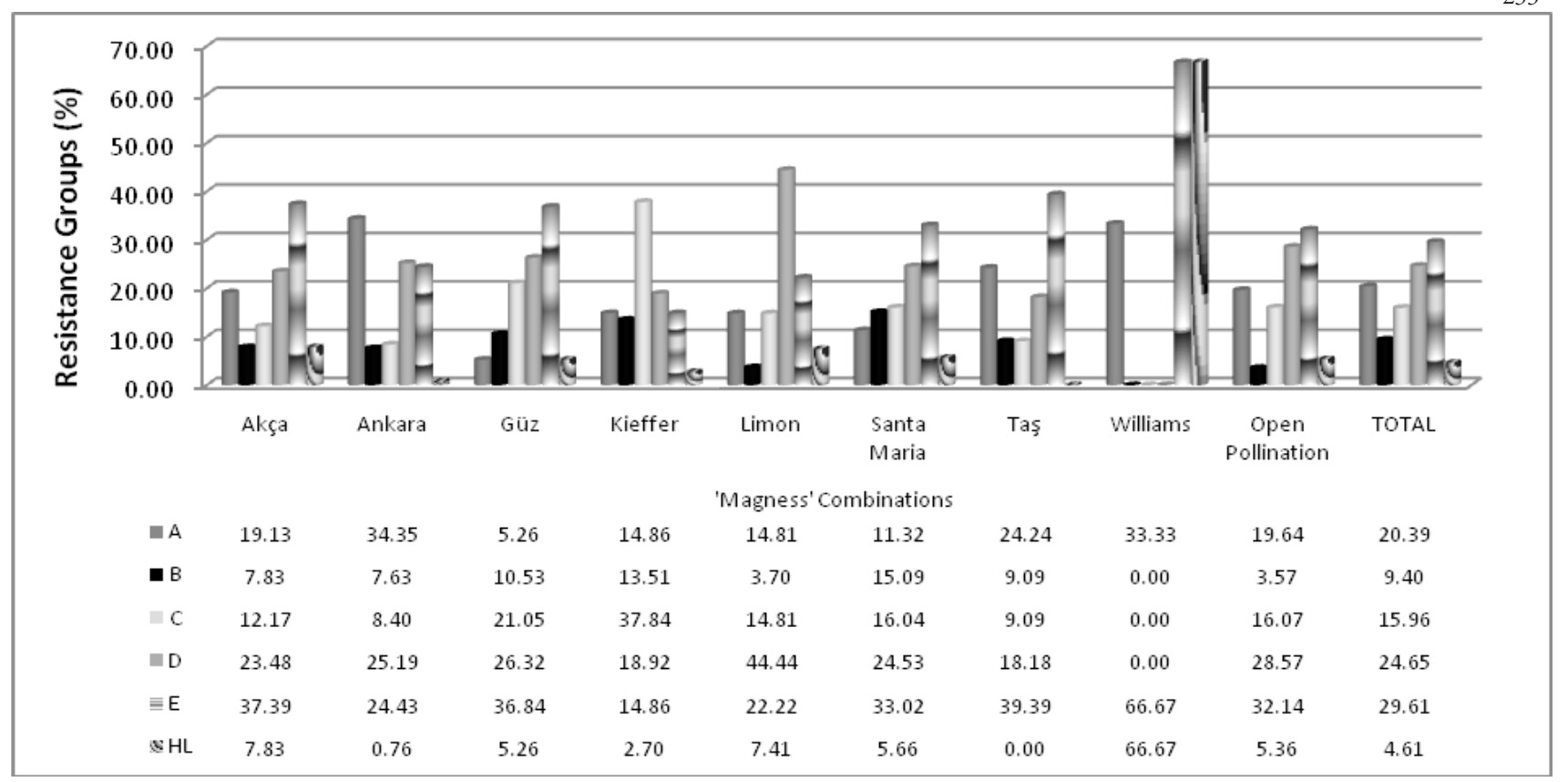

Fig. 8. Distribution of 'Magness' hybrids to susceptibility classes (\%)

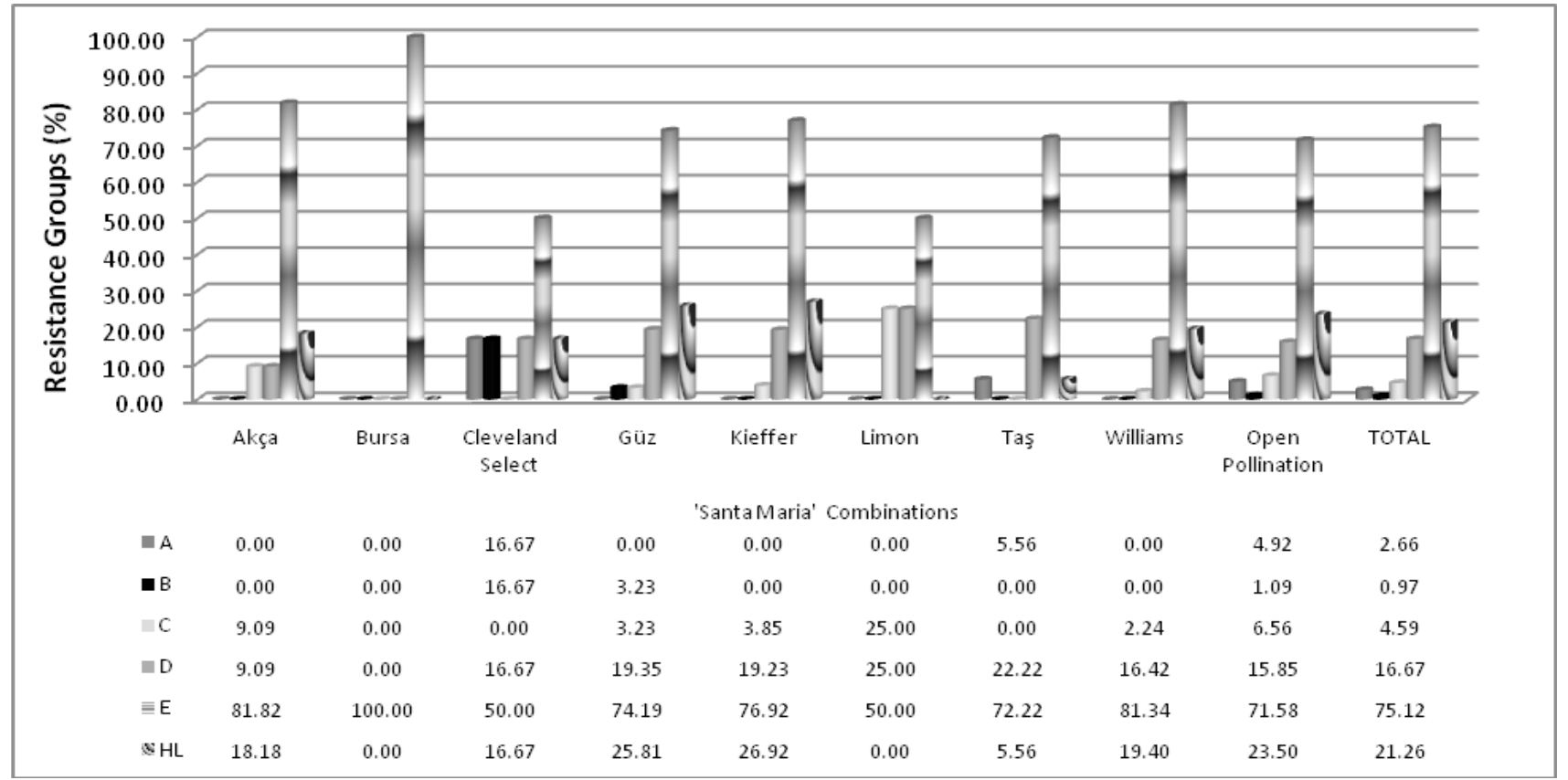

Fig. 9. Distribution of 'Santa Maria' hybrids to susceptibility classes (\%)

sufficiently good results were attained with respect to class "A" hybrids.

Distribution of the hybrids through cross combinations was counted as pencentage for two years together (Fig. 6, 7, 8, 9, 10). Among 'Akça' combinations, 'Kieffer' pollinator had maximum class "A" hybrids (26.67\%), and it was followed by 'Kaiser Alexandre' pollinator (5\%) and open pollination (4.14\%). On the contrary, a minimum class "E" hybrid number was found in 'Kieffer' pollinator $(53.33 \%)$ and it was followed by open pollination (55.03\%). Maximum hybrid loss was detected in 'Akça' $\mathrm{x}$ 'Conference' combination for two years (Fig. 6).
All the 'Güz' hybrids were obtained from open pollination, and the same distribution occured in both " $D$ " and "E" classes. For 'Kieffer'combinations, "slightly susceptible- A" hybrid ratio of open pollination (6.96\%) was much higher than of 'Santa Maria' cross combination (3.21\%). As for 'Mustafa Bey' parent, 'Moonglow' pollinator possessed the first (26.83\%), 'Güz' pollinator had the second (25\%), and 'Williams' pollinator had the last row (8.33\%) regarding class " $\mathrm{A}$ " hybrids as it was expected through the resistance condition of the pollinators (Fig. 7).

Distribution of 'Magness' hybrids according to susceptibility classes (\%) can be seen in Fig. 8. There were "slightly 


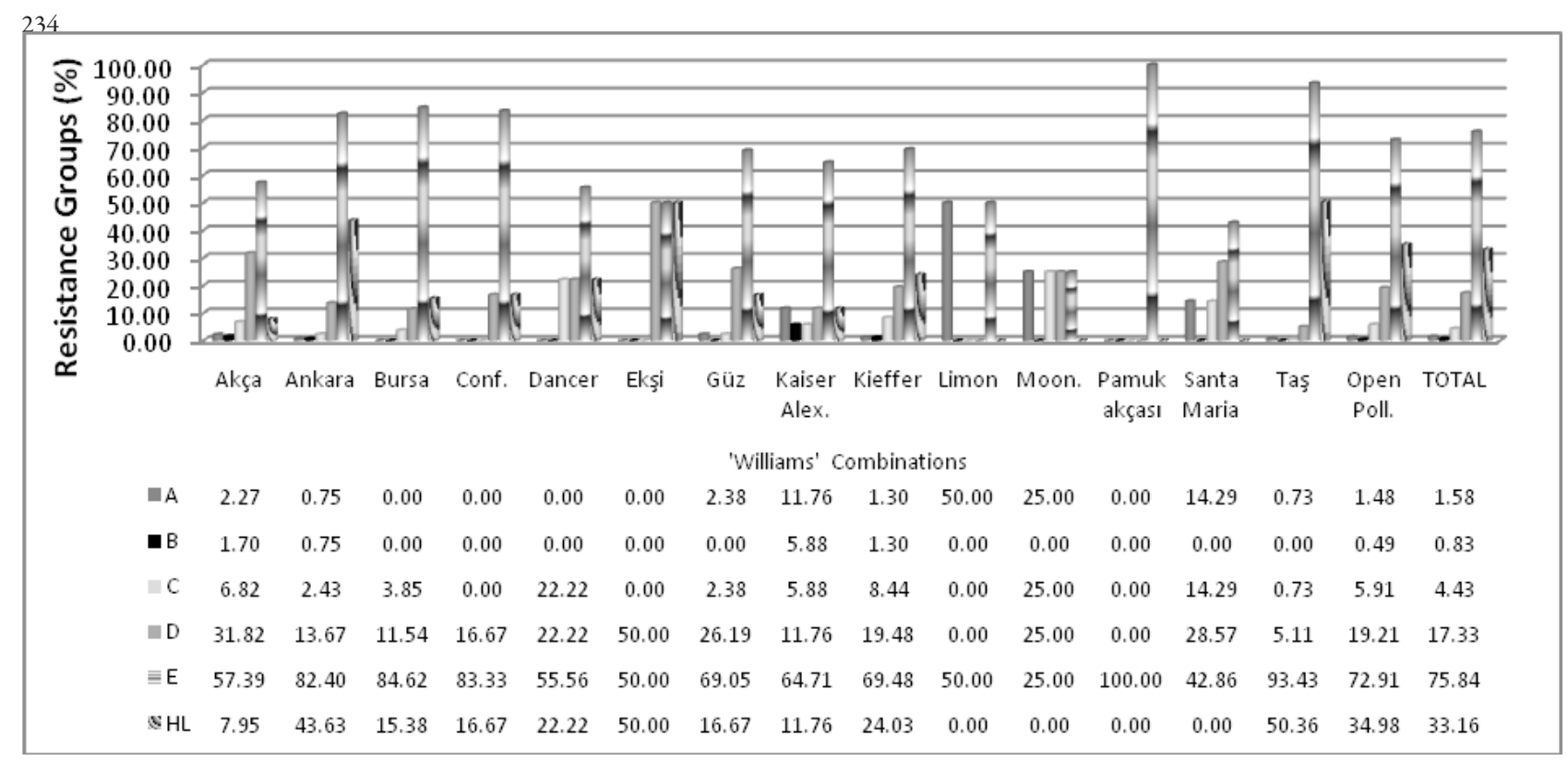

Fig. 10. Distribution of 'Williams' hybrids to susceptibility classes (\%)

susceptible- A" hybrids in every combination of 'Magness' cultivar, and 'Ankara' pollinator (34.35\%) ranked the first row among them. Almost in every combination (except 'Williams') there were hybrids in each susceptibility class and hybrid distribution to the classes was more balanced than the other maternal parents (Fig. 8).

In 'Santa Maria' cultivar, it was seen that 'Cleveland Select' (16.67\%) and 'Taş' (5.56\%) combinations, and open pollination (4.92\%) possessed class "A" hybrids (Fig. 8). Most of the hybrids were detected in class " $E$ " in every combination. There were notable class " $\mathrm{B}$ " hybrids in 'Cleveland Select' combination (16.67\%), and class "C" hybrids in 'Akça' combination (9.09\%), and open pollination (6.56\%) (Fig. 9).

Similar to 'Santa Maria' cultivar, most of the hybrids were determined in "very susceptible- E" character for 'Williams' maternal parent, too. 50\% of 'Limon' combination, 25\% of 'Moonglow' combination, 14.29\% of 'Santa Maria' combination, and $11.76 \%$ of 'Kaiser Alexandre' combination involved in class "A". Total hybrid loss for 'Williams' combinations was remarkable as $33.16 \%$ value (Fig. 10).

Although, 'Moonglow', 'Dancer', 'Taş', 'Kieffer', 'Limon', 'Conference,' 'Ekşi', 'Pamuk Akçası', and 'Güz' cultigens were stated as resistant to fire blight (Aysan et al., 1999; Bell et al., 2005; Çı1tır and Mırık, 1999; Honty et al., 2006; Momol et al., 1992; Sobiczewski et al., 1997; Ünal et al., 1998; van Der Zwet and Beer, 1991), any "slightly susceptible- A" hybrid could not be obtained from some susceptible $\mathrm{x}$ resistant combinations of these pollinator cultigens ('Akça' x 'Güz', 'Akça' x 'Moonglow', 'Akça' x 'Taş', 'Santa Maria' x 'Bursa, 'Santa Maria' x 'Güz,' 'Santa Maria’ x 'Kieffer', 'Santa Maria’ x 'Limon', 'Williams' x 'Bursa, 'Williams' x 'Conference', 'Williams' x 'Dancer', 'Williams' x 'Ekşi', 'Williams' x 'Pamuk Akçası'). Similarly, Sestras et al. (2008) reported that some cultivars known as resistant were defined as susceptible to fire blight attack in some conditions; for example 'Old Home' and 'Moonglow' cultivars. On the hand, 'Akça', 'Santa Maria' and 'Williams' cultivars are known as susceptible to fire blight (Aysan et al., 1999; Çıtır and Mırık, 1999; Momol et al., 1992; Öden, 1999; Sobiczewski et al., 1997; van Der Zwet and Beer, 1991), but, in some resistant x susceptible combinations of these cultivars ('Kieffer' x 'Santa Maria', 'Magness' x 'Akça,' 'Magness' x 'Santa Maria,' 'Magness' x 'Williams'), hybrid numbers in class "A" was high, in our investigation. Besides, some resistant hybrids were obtained from susceptible x susceptible combination like 'Williams' x 'Santa Maria. These data are parallel to the results obtained by Sestras et al. (2008). They stated that, a certain inconstancy of the cultivars reaction to Erwinia attack was noticed, as some are known as resistant or tolerant being susceptible or the contrary. 'Williams' considered highly susceptible included in the no attack class. So, in this research, the resistance level of the hybrids from various combinations differed among the cultivars used for cross pollination.

In another research concerning the testing of 85 hybrids, differences were observed between crosses in terms of the degree of resistance. A stable resistance level could not be detected for any of the species owing to these variations. It was observed that, resistance could not be transferred optimally in highly resistant $\mathrm{x}$ highly susceptible or highly resistant $\mathrm{x}$ highly resistant hybrid combinations. On the contrary, when two medium resistant parents combined, a maximum resistance level could be obtained (van Der Zwet et al., 1974).

\section{Conclusions}

It can be concluded that a total of 2631 hybrids of inoculated 3284 hybrids survived and distributed to different susceptibility classes. $19.88 \%$ of the inoculated hybrids 
was killed by Erwinia amylovora bacteria. As for total distribution of the hybrids to resistance classes, $6.18 \%$ of all hybrids involved in class "A", $3.11 \%$ of them were in class "B", $8.89 \%$ were in class "C", $20.28 \%$ were in class " $D$ ", and $61.54 \%$ were in class " $\mathrm{E}$ ".

It was detected that the number of "slightly susceptible-A" hybrids was much higher in combinations of resistant maternal parents, when compared to combinations of susceptible maternal parents, in 2007 and 2008 hybrids. When these resistant cultivars used as pollinators, it could not be possible to get the same remarkable conclusion. Besides, when susceptible cultivars were used as pollinators for these resistant maternal parents, sufficiently good results were attained with respect to class " $\mathrm{A}$ " hybrids.

Additionally, a wide range of class "A" hybrids were obtained from 'Magness' x 'Ankara' combination. 'Kieffer' x 'Santa Maria,' 'Kieffer' open pollination, 'Magness' x 'Akça', 'Magness' x 'Kieffer', 'Magness' x 'Santa Maria', 'Mustafa Bey' $x$ 'Moonglow' treatments displayed successful results with respect to "slightly susceptible- A" character. Moreover, it can be asserted that more hybridization combination leads to more hybrid number, and resistant hybrids.

As a result, the testing of hybrid population by artificial inoculation is very important from the point of view of obtaining new disease resistant cultivar candidate hybrids. Advanced evaluations must be performed in gained hybrid population regarding different fruit and tree characteristics.

\section{Acknowledgements}

This project was supported by TUBITAK (TOVAG 1060719).

We thank Yeşim Aysan for her contribution to isolate and obtain the E. amylovora for this research.

\section{References}

Aysan Y, Tokgönül S, Çınar Ö, Küden A (1999). Biological, chemical, cultural control methods and determination resistant cultivars to fire blight in pear orchards in the Eastern Mediterranean Region of Turkey. Acta Hort 489:549-553.

Aysan Y, Sahin F, Saygili H, Mirik M, Kotan R (2004). Phenotypic characterization of Erwinia amylovora from pome fruits in Turkey, $10^{\text {th }}$ International Workshop on Fire Blight, Bologna, Italy, Acta Hort 704:459-463.

Bell AC, Ranney TG, Eaker TA, Sutton TB (2005). Resistance to fire blight among flowering pears and quince. Hortscience 40(2):413-415.

Bergamaschi M, Rivalta L, Sirri S, Biondi E, Ramili F, Bazzi C (2006). Reactivity to fire blight of new promising pear selections. Acta Hort 704:571-577.

Çıtır A, Mirik M (1999). Fire blight of pome fruits and search for resistant or tolerant cultivars in Amasya and Tokat Regions in Turkey. Acta Hort 489:215-220.

Durel CE, Guérif P, Belouin A, Le Lezec M (2004). Estimation of fire blight resistance heritability in the French 235 breeding program using a pedigree-based approach. Acta Hort 663:251-256.

Evrenosoğlu Y, Misırlı A, Akçay ME, Ünal A, Acarsoy N, Özdemir N, Bilen E, Boztepe Ö, Günen E (2010). Variability of different pear hybrid populations in terms of hybridization performance and the response to fire blight (Erwinia amylovora) attack. Not Bot Hort Agrobot Cluj 38 (1):241-247.

Fischer M, Mildenberger G (2000). New Naumburg/Pillnitz pear breeding results. Acta Hort 538:735-739.

Hevesi M, Göndör M, Kása K, Honty K, Tóth MG (2004). Traditional and commercial apple and pear cultivars as sources of resistance to fireblight. EPPO/OEPP Bulletin 34(3):377-380.

Honty K, Göndör M, Toth M, Kasa K, Hevesi M (2006). Susceptibility of pear cultivars to fire blight in Hungary. Acta Hort 704:583-587.

Hunter DM, Layne REC (2004). Recent pear and apricot introductions from the aafc-harrow tree fruit breeding programs. Acta Hort 663:907-910.

Işsk EA, Çelik M (2009). Similarities between pomegranate parents and crosses regarding some fruit characteristics. I. International Symposium on Pomegranate and Minor Mediterranean Fruits, Adana-Turkey, 2006, Acta Hort $818: 229-232$.

Layne EC, Quamme HA (1975). Pears, p. 38-70. In: Janick J, Moore JN (Eds.). Advances in fruit breeding. Purdue University Press, West Lafayette, Indiana.

McGraw D (2006). Pollination requirements for fruits and nuts. Oklahama Cooperative Extension Fact Sheets. F-6229.

MomolMT, Yeğen O, Basım H, Rudolph K(1992).Identification of Erwinia amylovora and the occurrence of fire blight of pear in Western Mediterranean region of Turkey. Journal of Turkish Phytopathology 21(1):41-47.

Öden S (1999). Occurrence of fire blight in pear trees grown in Van and around. Acta Hort 489:107-111.

Quamme HA, Van Der Zwet T, Dirks V (1976). Relation of fireblight resistance of young pear seedlings inoculated in the greenhouse to mature seedlings trees naturally infected in the field. Plant Dis Reptr 60:660-664.

Rosati C, Rivalta L, Dradi M, Le Lézec M, Belouin A, Chartier R (2002). Fireblight evaluation of advanced Italian selections and cultivars of pear. Acta Hort 596:279-282.

Ryugo K (1982). Breeding resistance to fire-blight bacteria, Erwinia amylovora, in pears. Acta Hort. 124:33-36.

Sestras A, Sestras R, Barbos A, Madalina M (2008). The differences among pear genotypes to fire blight (Erwinia amylovora) attack, based on observations of natural infection. Not Bot Hort Agrobot Cluj 36(2):98-103.

Shay JR, Williams EB, Janick J (1962). Disease resistance in apple and pear. Proceedings of the American Society for Horticultural Science 80:97-104. 
236

Sobiczewski P, Deckers T, Pulawska J (1997). Fire Blight (Erwinia amylovora), Some Aspects of Epidemiology and Control. Research Institute of Pomology and Floriculture, Skierniewice, Poland.

Thibault B, Lecomp P, Hermann L, Belouin A (1987). Assesment of the susceptibility to Erwinia amylovora of the 90 varieties or selections of pear, Acta Hort 217:305-309.

Thibault B, Lezec ML (1990). Fireblight of Pomoidae (E. amylovora Burrill, Winslow et al.). Agrimed research programme. Applied Research in Europe (1978-88) EUR 12601:96-109.

Thompson SS, Janick J, Williams EB (1975). Evaluation of resistance to fire blight of pear, p. 610. Janick J, Moore JN (Eds.). Purdue University Press, West Lafayette, Indiana,

Ünal A, Saygılı H, Hepaksoy S, Türküsay H, Can Z (1998). Researches on determining pear varieties resistant to fire blight (Erwinia amylovora (Burril.)Winslow et al.) in the Western Anatolia. TÜBİTAK, TOGTAG Project number 1247. Final Report.
Van der Zwet T, Oitto WA, Westwood MN (1974). Variability in degree of fire blight resistance within and between Pyrus species, interspecific hybrids, and seedling progenies. Euphytica 23(2):295-304.

Van der Zwet T, Beer SV (1991). Fire Blight-It's Nature, Prevention and Control: A Practical Guide to Integrated Disease Management. U. S. Department of Agriculture, Agriculture Information Bulletin No. 631.

Van der Zwet, T, Beer SV (1995). Fire Blight -It's Nature, Prevention and Control: A Practical Guide to Integrated Disease Management, U. S. Department of Agriculture, Agriculture Information Bulletin No. 631.

Vanneste JL (2000). Fire Blight, The Disease and It's Causative Agent Erwinia amylovora, HortResearch, Hamilton-New Zealand, CABI Publishing, p.370. 